\title{
Considerations for lactation with Ehlers- Danlos syndrome: a narrative review
}

\author{
Jimi Francis ${ }^{1^{*}}$ (D) and Darby D. Dickton ${ }^{2}$
}

\begin{abstract}
Background: Ehlers-Danlos syndrome (EDS) is a rare genetic connective tissue condition that is poorly understood in relation to lactation. As diagnostic methods improve, prevalence has increased. EDS, a disorder that impacts connective tissue, is characterized by skin extensibility, joint hypermobility, and fragile tissue which can affect every organ and body system leading to complications during pregnancy, delivery, and the postpartum period. Traits of this disease can cause mild to severe physiologic and functional obstacles during lactation. Unfortunately, there is little clinical evidence and minimal guidance for lactation management, and providers may feel uncomfortable and hesitant to address these concerns with patients due to a lack of readily available resources on the subject and inexperience with such patients. This narrative review describes and discusses the types of EDS, identifying symptoms, considerations, and precautions for care providers to implement during lactation and breastfeeding.

Methods: An electronic search of relevant citations was conducted using the databases Cochrane, PubMed, and Google Scholar from 1 January 2000 to 1 November 2021. Search terms used were Ehlers-Danlos syndrome, Hypermobility Syndrome, breastfeeding, lactation, breastmilk expression, breastmilk collection, human milk expression, human milk collection, and infant feeding. The search of these databases yielded zero results. As no research articles on EDS were directly related to lactation, this narrative review includes articles found that related to the health of mothers relevant to maternal function during lactation.

Discussion: For the healthcare provider, identifying characteristics of EDS can improve the management of lactation challenges. Mothers may experience generalized symptoms from gastrointestinal distress to fatigue or chronic pain, while they also may suffer from more specific joint complaints and injuries, such as dislocations / subluxations, or skin fragility. Such obstacles can generate impediments to breastfeeding and create unique challenges for breastfeeding mothers with EDS.

Unfortunately, new mothers with these symptoms may have them overlooked or not addressed, impacting a mother's ability to meet her breastfeeding intentions. While there are some published research manuscripts on EDS and pregnancy, there is a lack of information regarding breastfeeding and lactation. Additional research is needed to help guide EDS mothers to achieve their breastfeeding intentions.
\end{abstract}

Keywords: Ehlers-Danlos, EDS hypermobility syndrome, Rare disease, Breastfeeding barriers, Breastfeeding support

\footnotetext{
* Correspondence: jimi.francis@utsa.edu

${ }^{1}$ University of Texas at San Antonio Libraries, San Antonio, TX, USA

Full list of author information is available at the end of the article
}

(c) The Author(s). 2021 Open Access This article is licensed under a Creative Commons Attribution 4.0 International License, which permits use, sharing, adaptation, distribution and reproduction in any medium or format, as long as you give appropriate credit to the original author(s) and the source, provide a link to the Creative Commons licence, and indicate if changes were made. The images or other third party material in this article are included in the article's Creative Commons licence, unless indicated otherwise in a credit line to the material. If material is not included in the article's Creative Commons licence and your intended use is not permitted by statutory regulation or exceeds the permitted use, you will need to obtain permission directly from the copyright holder. To view a copy of this licence, visit http://creativecommons.org/licenses/by/4.0/. The Creative Commons Public Domain Dedication waiver (http://creativecommons.org/publicdomain/zero/1.0/) applies to the data made available in this article, unless otherwise stated in a credit line to the data. 


\section{Background}

Ehlers-Danlos syndrome (EDS) is a rare genetic connective tissue condition that is poorly understood in relation to lactation but can be characterized by skin extensibility, joint hypermobility, and fragile tissue. These traits can cause physiologic and functional obstacles to breastfeeding for mothers with EDS. Currently, there are 13 recognized subtypes, mainly categorized by key physical determinants that capture the distinctive signs and symptoms of each phenotype. The various EDS manifestations are diagnosed based on the 2017 International Classification-Diagnostic criteria for EDS [1] shown in Table 1. EDS is most often diagnosed by a physician in conjunction with a subsequent referral to a genetic specialist for further evaluation and subcategorization [2]. As determined by a physical evaluation and genetic testing, providers subcategorize these patients in order to accurately identify appropriate risk stratification. Risk stratification helps determine what follow up or imaging is needed over the patient's lifetime based on the EDS subtype, patient's age, and symptom onset. Currently, EDS subcategories, many associated with genetic markers, are caused by tissue specific collagen defects usually causing damage to particular systems. For example, there is an Ocular subtype that is defined by

Table 1 Phenotypic presentation of EDS subtypes pertinent to lactation

\begin{tabular}{lll}
\hline EDS Subtype & Protein involved & Genetic basis \\
\hline Classical & Type V collagen & COL5A1 \\
& COL5A2 \\
Type I collagen & COL1A1 (Rarely) \\
Classical-like & Tenascin XB & TNXB \\
Cardiac-valvular & Type I collagen & COL1A2 \\
Vascular & Type III collagen & COL3A1 \\
Hypermobile & Unknown & Unknown \\
Arthrochalasia & Type I collagen & COL1A1 \\
& & COL1A2 \\
Dermatosparaxis & ADAMTS2 & ADAMTS-2 \\
Kyphoscoliotic & PLOD1 & LH1 \\
Brittle cornea syndrome & FKBP14 & FKBP22 \\
Spondylodysplastic & PRDM5 & ZNF469 \\
& B4GALT7 & PRDM5 \\
Periodontal & B3GALT6 & B4GALT7 \\
\hline
\end{tabular}

the predominant phenotypical expression in the sclera [3], and a Spinal subtype that is defined by extreme vertebral joint laxity causing spinal malalignment [4]. Though most subtypes have been successfully identified genetically [5], Hypermobility EDS seems particularly elusive to genetic linking [2]. As this subtype has not yet been isolated in the genetic code and cannot be diagnosed with genetic testing, it is important to emphasize genetic associations are not required for an EhlersDanlos syndrome diagnosis. If no link can be identified, EDS can be diagnosed by phenotypic presentation and at the exclusion of other hypermobility disorders by a physician [6].

Foundationally, EDS causes dysfunction in collagen fibers and while subtypes describe specific body systems or mechanisms that are more directly affected [7], all patients with EDS, to some extent, experience generalized, broad systemic complaints. Tissue laxity (often identified as "stretchy skin"), joint hypermobility (frequently identified as "loose / unstable joints"), difficulties with proprioception, or acute awareness of where body parts are in space, and other generalized systemic problems such as intestinal dysmotility, impaired healing, and inappropriate scarring can be present [8]. Due to the proprioception abnormalities, patients with EDS are frequently unaware their joints are sliding out of alignment or into a dangerously hyper-flexed or hyper-extended state until they experience pain. On a cellular level, in normal individuals, connective tissue provides strength, structure, and elasticity to body systems allowing movement within normal limits but not beyond those limits [9]. Connective tissue in the EDS mother can and will allow for unintentional movement beyond normal limits ranging from mild examples such as ligament strain from hyperextension to more severe manifestations such as dislocations, causing chronic forms of damage, pain, and dysfunction [10].

While it was once thought to be an extraordinarily rare condition, the prevalence of EDS using newer estimation models could be as common as 194 per 100,000 in 2016 / 2017 [11]. As genetic research has increased greatly in this area, the understanding of EDS subtypes and variations has become an expanding field of study [8]. There can be an overlap of signs and symptoms with other connective tissue disorders and, challengingly, some current definitions for clinical criteria are nonspecific. Given the infrequency of provider-patient interactions for this disease, even fewer providers feel comfortable making the necessary recommendations [12] or adjustments to improve the mother-baby experience of new mothers coping with EDS.

As EDS is a disorder that impacts connective tissue, every organ and body system can be affected by poor structural integrity, and when combined with the major 
physiologic and physical changes of pregnancy due to the hormone relaxin, a pleiotropic hormone [13], complications are common during pregnancy and at delivery, including uterine rupture, precipitous delivery $(<4 \mathrm{~h})$, arterial dissection / rupture, and miscarriage $[14,15]$. These complications can create impediments to lactation, whether feeding a baby at the breast or expressing milk. Other unique challenges arise given the weight of mammary tissue during lactation, especially during secretory activation, with the increased laxity of Cooper's ligaments, which suspend breast tissue. Pain caused by the stretching of the ligaments can make the positioning and the ergonomics of feeding at the breast challenging, as well as potentially interfering with and / or inhibiting milk production or flow. Unfortunately, a lack of readily available resources on the subject [16] paired with little clinical evidence means there is minimal guidance for optimal lactation management of EDS patients, making many providers hesitant to offer care recommendations [17]. Based on the authors' experience this can make a diagnosis of EDS challenging and often translates into general apprehension for clinicians managing mothers with EDS.

The purpose of this narrative review is to describe and synthesize the available information that pertains to caring for lactating mothers with EDS. Increasing the understanding of the syndrome and the impact various subtypes may pose for lactation is crucial for better management and support of those new mothers coping with EDS while lactating, whether feeding at the breast and / or expressing their milk. While this review focuses on EDS, the following recommendations are based on symptomatic presentations that could be applied to other similar systemic diseases.

\section{Methods}

An electronic search of relevant citations was conducted using databases Cochrane, PubMed, and Google Scholar. The keyword search terms were Ehlers-Danlos syndrome, Hypermobility Syndrome, breastfeeding, lactation, breastmilk expression, breastmilk collection, human milk expression, human milk collection, and infant feeding. The dates for this search were from 1 January 2000 to 1 November 2021. The search of Cochrane, PubMed, and Google Scholar yielded zero results. As no research articles on EDS were directly related to lactation, this narrative review includes articles found that related to the health of mothers relevant to maternal function during lactation. This narrative review includes information based on general and specific complaints associated with EDS which are pertinent to lactation.

\section{Discussion}

Mothers with EDS may be frustrated by providers unable to diagnose their reports of pain or system-wide disturbances [12]. Identifying characteristic of EDS and providing supportive care can improve the management of lactation challenges. For the ease of reference, the topics have been organized by relevant body system. Specific complaints or challenges are addressed under these body systems headings. Strategies pertinent to EDS management during lactation are shown in Table $2[1,3$, $4,6,9,14]$.

\section{Joints and muscles}

In patients with EDS, dislocations and / or subluxations can occur with even the slightest pressure. For mothers with the syndrome, positioning a baby at the breast or supporting a breast heavy with milk can provoke such injuries. Routine tasks like hair washing may lead to shoulder dislocations with the breast weight changes associated with secretory activation in the early postpartum period. Even tasks which shift the weight of the breast, such as putting down the flap on a bra, or lack of support when latching the infant, can cause internal stress in the breast tissue [18]. On a microscopic level, subtle shifts of the increased mass of breast tissue can cause shearing injuries to the smallest areas of the circummammary ligaments [19] dispersed throughout the breast as superficial tissue moves in one direction while the deeper tissue moves in a different direction [20]. Educating mothers on multiple positions for breastfeeding and assisting them with guided practice during pregnancy can help mothers with EDS build confidence as well as identifying problem areas that may need bracing, such as wrists or fingers. The lactation specialist can help them create adequate physical support using pillows or blanket rolls to minimize strains and prevent injuries based on the mother's needs. Techniques to reinforce appropriate posture and ergonomics can also address the difficulties for mothers who suffer joint strain due to lack of body awareness caused by the known proprioceptive abnormalities that may present in $\operatorname{EDS}[9,21]$. Preparation for infant care and practicing these tasks during pregnancy with slow, controlled strength conditioning can reduce injury risk with simple routine tasks or repeated motions, like putting on a bra, or picking up their infant, which can cause varying degrees of injury to the ligaments of the shoulder [22]. Reminding patients, who struggle with suspected shearing injuries, to support the breast while bringing the infant to the breast rather than bringing the breast to the infant can be particularly prudent to decrease the risk of circummammary ligament damage in mothers with EDS. While wearing a supportive bra, joint braces, proprioceptive garments, using physical supports, and regular, specific physical strengthening can decrease the risk of injury, it is important to plan for pain management [23] of injuries so that these mothers can be empowered with skills to optimize their situation. Establishing relationships with other care providers to create a 
Table 2 Strategies pertinent to EDS management during lactation

\begin{tabular}{|c|c|c|c|c|}
\hline \multirow[t]{2}{*}{ EDS Subtype } & \multirow[t]{2}{*}{ Sign-symptoms } & \multicolumn{3}{|l|}{ Suggestions for breastfeeding support } \\
\hline & & During pregnancy & $\begin{array}{l}\text { Initiating } \\
\text { breastfeeding }\end{array}$ & Throughout lactation \\
\hline \multirow[t]{2}{*}{ Classical } & \multirow[t]{2}{*}{$\begin{array}{l}\text { *Skin can be easily torn and will } \\
\text { not repair itself well or quickly } \\
\text { *Joint hypermobility } \\
\text { *Atrophic scarring, poor healing } \\
\text { *Skin hyper-extensibility }\end{array}$} & $\begin{array}{l}\text { Providing breastfeeding education early } \\
\text { in the third trimester can be helpful as } \\
\text { preterm labor can occur }\end{array}$ & $\begin{array}{l}\text { Prevent nipple trauma } \\
\text { through early } \\
\text { evaluation of latch }\end{array}$ & $\begin{array}{l}\text { Prevent scarring and } \\
\text { manage wounds with } \\
\text { on-going feeding } \\
\text { assessment }\end{array}$ \\
\hline & & $\begin{array}{l}\text { Splinting the pelvis, ligaments, and } \\
\text { joints can help with pelvic pain }\end{array}$ & $\begin{array}{l}\text { Assess positioning } \\
\text { during breastfeeding } \\
\text { to prevent injury }\end{array}$ & $\begin{array}{l}\text { Frequent feedings and } \\
\text { slow weaning minimize } \\
\text { engorgement }\end{array}$ \\
\hline Classical-like & $\begin{array}{l}\text { *Soft-velvety skin (without the } \\
\text { typical atrophic scarring seen in } \\
\text { classical EDS) leads to easy } \\
\text { irritation. }\end{array}$ & $\begin{array}{l}\text { Be conscious of rough fabrics and } \\
\text { materials including silicone which can } \\
\text { stick to the skin and must be removed } \\
\text { gently to avoid tearing of the skin }\end{array}$ & $\begin{array}{l}\text { Ensure optimized latch. } \\
\text { Gentle breast massage } \\
\text { may be useful for } \\
\text { alleviating discomfort } \\
\text { of secretory activation }\end{array}$ & $\begin{array}{l}\text { Avoid positions and } \\
\text { equipment that shear or } \\
\text { create torsion of the } \\
\text { tissue }\end{array}$ \\
\hline Cardiac-valvular & $\begin{array}{l}\text { Progressive cardiac and valve } \\
\text { problems } \\
\text { Dizziness and fainting can occur }\end{array}$ & $\begin{array}{l}\text { Will likely require regular follow-up with } \\
\text { Cardiology } \\
\text { Practice slow standing }\end{array}$ & $\begin{array}{l}\text { Will likely require } \\
\text { follow-up with } \\
\text { Cardiology } \\
\text { Report palpitations and } \\
\text { new symptoms }\end{array}$ & $\begin{array}{l}\text { Reminders to pick the } \\
\text { infant up after standing } \\
\text { can help prevent falls }\end{array}$ \\
\hline Vascular & $\begin{array}{l}\text { Unusual bruising for no } \\
\text { apparent cause } \\
\text { Postpartum hemorrhage can } \\
\text { occur }\end{array}$ & $\begin{array}{l}\text { Monitor for orthostatic difficulties, and } \\
\text { practice safe habits when first standing; } \\
\text { avoid rushed movements }\end{array}$ & $\begin{array}{l}\text { Placing the infant skin- } \\
\text { to-skin within the first } \\
\text { hour of life is crucial }\end{array}$ & $\begin{array}{l}\text { Reminders to pick the } \\
\text { infant up after standing } \\
\text { can help prevent falls }\end{array}$ \\
\hline Hypermobile & $\begin{array}{l}\text { Severe generalized joint } \\
\text { hypermobility. Separation of the } \\
\text { pubic symphysis and coccyx } \\
\text { dislocation have been reported }\end{array}$ & $\begin{array}{l}\text { Prevent injuries using focused and slow } \\
\text { movements }\end{array}$ & $\begin{array}{l}\text { Physical support and } \\
\text { positioning } \\
\text { modifications may be } \\
\text { needed for basic infant } \\
\text { care }\end{array}$ & $\begin{array}{l}\text { Monitor for increasing } \\
\text { pain difficulties, check } \\
\text { safety of medication } \\
\text { regimen for } \\
\text { breastfeeding }\end{array}$ \\
\hline Arthrochalasia & $\begin{array}{l}\text { Multiple dislocations and / or } \\
\text { subluxations }\end{array}$ & $\begin{array}{l}\text { Prepare to practice aggressive, daily } \\
\text { splinting measures to support joints }\end{array}$ & $\begin{array}{l}\text { Exercise caution with } \\
\text { movements and } \\
\text { monitor for tissue } \\
\text { trauma }\end{array}$ & $\begin{array}{l}\text { Can complicate use of a } \\
\text { breast pump }\end{array}$ \\
\hline Dermatosparaxis & $\begin{array}{l}\text { Extreme skin fragility and severe } \\
\text { susceptibility of bruising }\end{array}$ & $\begin{array}{l}\text { Requires a specific focus on skin care } \\
\text { and precautions }\end{array}$ & $\begin{array}{l}\text { Consider use of skin } \\
\text { barrier protectant if } \\
\text { using a pump }\end{array}$ & $\begin{array}{l}\text { Monitor for chronic } \\
\text { wound development }\end{array}$ \\
\hline Kyphoscoliotic & $\begin{array}{l}\text { Dislocations and / or } \\
\text { subluxations of the shoulders, } \\
\text { hips and knees }\end{array}$ & $\begin{array}{l}\text { Abdominal bracing may be beneficial } \\
\text { during the third trimester }\end{array}$ & $\begin{array}{l}\text { For hearing loss may } \\
\text { need visual alerts to } \\
\text { signal infant needs }\end{array}$ & $\begin{array}{l}\text { Special considerations } \\
\text { should be given to } \\
\text { ergonomics when seated }\end{array}$ \\
\hline $\begin{array}{l}\text { Brittle cornea } \\
\text { syndrome }\end{array}$ & Practice classic considerations & $\begin{array}{l}\text { For new symptoms, seek medical eye } \\
\text { care }\end{array}$ & $\begin{array}{l}\text { Use touch to increase } \\
\text { awareness of baby's } \\
\text { positioning if difficulty } \\
\text { seeing }\end{array}$ & $\begin{array}{l}\text { Identify strategies to } \\
\text { assist in infant care that } \\
\text { are touch or sound } \\
\text { focused }\end{array}$ \\
\hline Spondylodysplastic & $\begin{array}{l}\text { Reduced muscle tone and } \\
\text { rigidity can occur }\end{array}$ & $\begin{array}{l}\text { Refer to physical therapist; stretching } \\
\text { needs to be carefully balanced with } \\
\text { strengthening }\end{array}$ & $\begin{array}{l}\text { Match comfort with } \\
\text { good ergonomic } \\
\text { positioning to prevent } \\
\text { injuries }\end{array}$ & $\begin{array}{l}\text { Watch for good } \\
\text { ergonomic positioning } \\
\text { to improve long term } \\
\text { outcomes }\end{array}$ \\
\hline Musculocontractural & Risk for hematomas & $\begin{array}{l}\text { Practice skin and tissue considerations } \\
\text { An exercise ball may be helpful }\end{array}$ & $\begin{array}{l}\text { Use support devices to } \\
\text { use burden on } \\
\text { musculature }\end{array}$ & $\begin{array}{l}\text { Rehabilitative tape may } \\
\text { be useful to stabilize } \\
\text { ligaments during } \\
\text { breastfeeding sessions }\end{array}$ \\
\hline Myopathic & Muscle weakness & Use of a pelvic belt may be useful & $\begin{array}{l}\text { Mother may need } \\
\text { additional structural } \\
\text { and positioning } \\
\text { support during } \\
\text { lactation }\end{array}$ & $\begin{array}{l}\text { Monitor for chronic } \\
\text { symptom development } \\
\text { or worsening }\end{array}$ \\
\hline Periodontal & $\begin{array}{l}\text { Inflammation of the tissue } \\
\text { around teeth }\end{array}$ & $\begin{array}{l}\text { Can lead to food avoidance. Refer to a } \\
\text { dietitian / nutritionist to ensure } \\
\text { adequate food intake }\end{array}$ & $\begin{array}{l}\text { Follow-up with a } \\
\text { dietitian / nutritionist } \\
\text { to reassess nutritional } \\
\text { needs during lactation }\end{array}$ & $\begin{array}{l}\text { Continued follow-up } \\
\text { with a dietitian / nutri- } \\
\text { tionist to protect milk } \\
\text { production }\end{array}$ \\
\hline
\end{tabular}

*These traits will likely be seen in most EDS variations and as such these precautions should be considered in all EDS mothers 
health care team that includes ideally a physiotherapist and a nutritionist is important for the total care of these patients.

It is also important to note that EDS patients will often find positions such as tucking in their knees or crossing their legs provide temporary relief for muscle fatigue. These positions do slowly stretch out ligaments and tendons due to uncontrolled hyper-flexing during this muscle relaxation and can be damaging long-term if sustained for an extended period. Patients will often be unaware and should be educated and frequently reminded of these challenges to best initiate ergonomic posture strategies, particularly during feeding sessions. If left unchecked tucked in knees and crossed legs can cause further pain and joint instability.

\section{Pain}

EDS patients can have chronic pain, often from irritated joints and slow healing of injuries. This chronic pain requires appropriate pain interventions that serve to decrease pain intensity $[24,25]$. Many women with EDS experience neuropathic pain and / or small fiber neuropathy [26]. Their connective tissue can be hyper-elastic without resilience and fragile, but the nerves are not hyper-elastic. This may be a cause of pain, particularly if latch is poor or the infant is pulled from the breast without releasing the latch pressure. Raynaud's syndrome is also very common in EDS $[27,28]$ and can contribute to nipple and breast pain. Often, without awareness, EDS patients develop a fidget or erratic frequency to their movements to accommodate small muscle and nerve firings while protecting themselves from isolated muscle failure secondary to fatigue. It is common for EDS patients to have peripartum musculoskeletal [15] and visceral pain [29] which can be exacerbated by the surge of relaxin (which promotes connective tissue remodeling via increased collagen turnover) [30], essential for the ligamentous laxity necessary for pelvic flexibility to accommodate fetal development and vaginal delivery. While the surge peaks in the first trimester, it slowly decreases throughout the second trimester and maintains a stable level until parturition where it drops precipitously [31].

Although the relaxin level drops, the ligamentous laxity can persist into the postpartum period, compounding EDS symptoms, manifesting as pelvic floor distension creating pain or pelvic girdle discomfort. The weight of a lactating breast combined with ligament laxity can create a burning sensation deep in the breast (as reported to the authors in clinical practice). Warm compresses [32] and magnesium supplementation [33] have been reported to be helpful for alleviating symptoms. Nifedipine has been reported to successfully manage nipple vasospasms [34].

Use of a stability ball seat has been reported to the authors by EDS moms to give them a way to express the
EDS muscle fidget and use a variety of muscle groups to prevent the tiring of singular muscles. Rhythmic sensory stimulation [35], transcutaneous electrical nerve stimulation (TENS) [36], lidocaine patches [37], warming pads / compresses [38], and joint injections [39] may also be useful techniques to manage pain. Electronic methods and alternative remedies may need to be assessed in depth to ensure the mother is being informed fully as to the lactation considerations and risks while using these interventions.

Use of subtle bouncing on an exercise ball has also been reported to ease pelvic and low back discomfort during pregnancy, labor, and postnatally for non-EDS patients [40-42] and may be effective for EDS patients as reports to the authors indicate. Structurally speaking, splinting the pelvis, ligaments, and joints can help with pelvic pain. Sacro-iliac and uterine splinting can be particularly helpful in alleviating anterior and posterior pelvic discomfort. Pelvic discomfort can continue after the baby's birth and may require physiotherapy as well as analgesia for pain management [43]. Assisting new mothers to find adaptive measures for discomfort including supportive clothing and / or devices such as braces can minimize or prevent discomfort. Gentle breast massage [44] along with bracing and support garments was found to be useful for alleviating the pain manifesting from these various musculoskeletal microinjuries. However, the use of rehabilitative tape, designed originally as a ligamentous stabilizing adhesive [45] which creates physiologically appropriate tension to externally splint the body [46] and other therapeutic noninvasive joint support modalities, have been increasingly researched over the last several years [47]. Such principles can be applied well to the unique circumstance mothers with EDS encounter. However, it must be noted that rehabilitative tape should be used cautiously in mothers who have moderate to severe dermal manifestations of EDS. In mild cases, skin barrier film may help but the mother should be monitored to ensure a successful positive response. A diagram of possible tape positioning is shown in Fig. 1, provided in a personal communication by Bryna Sampey of Doula My Soul, IBCLC [48].

\section{Fatigue}

For EDS patients, pain is often associated with fatigue, which can be compounded by sleep deprivation that often accompanies the arrival of a neonate. Helping a new EDS mother with finding adequate resources to manage fatigue is especially important. These resources can include neighbors, friends, church members, and family who all want to help make life easier for the new mother as well as providing the additional assistance needed to promote successful lactation. Equally 

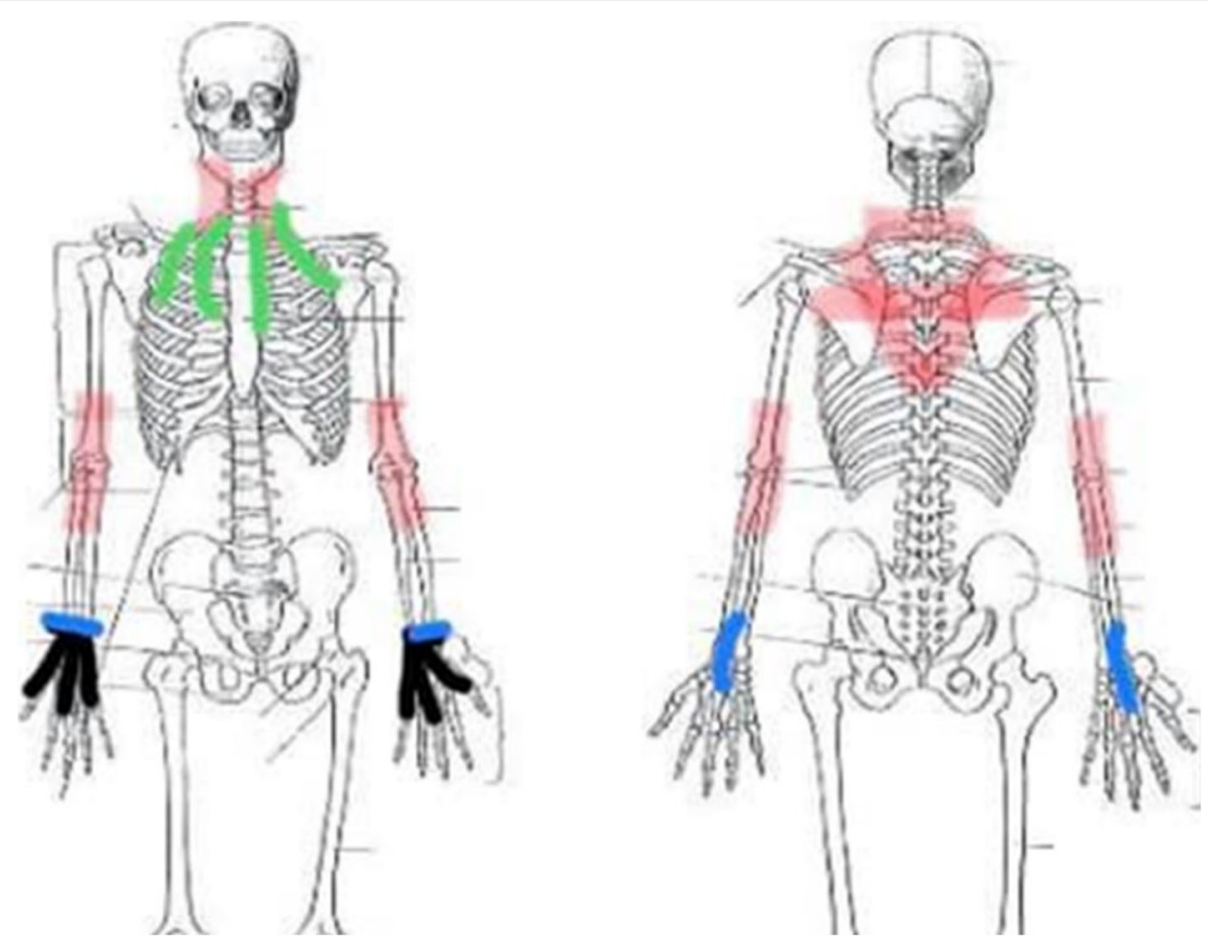

Fig. 1 Rehabilitative tape positioning

important is giving the mother with EDS a way to explain her condition and circumstances to those whom she chooses, so she might feel better understood. Encouraging her to reach out to her support network and accepting their "help", as they are often delighted to provide meals, occasional cleaning, or to deliver groceries as a way of allowing help with the new family that will leave the new mother more time to focus on managing her condition while acclimating to life with a new infant.

\section{Gastrointestinal}

Gastrointestinal problems include constipation, diarrhea, and / or reflux [49]. As people with EDS often experience nausea and abdominal pain that may decrease their desire to eat, adequate maternal nutrient intake can be a challenge [50]. If mothers with EDS experience diarrhea, it is essential that they stay hydrated for maternal wellbeing. Suggesting mothers place a glass of water on a table or nightstand where they will be feeding their infant at the breast can help them remember to maintain adequate hydration. Gastrointestinal effects are often dismissed as "stress-related" stomach issues and can be difficult to separate from stress related somatization [50, 51] It is also important for mothers suffering the gastrointestinal aspects of EDS to be monitored for malnutrition and weight maintenance during lactation.
Individuals with gastrointestinal symptoms may benefit from advice from a nutritionist.

\section{Skin and fascial tissues}

The skin of the EDS mother can be fragile [52], bruising or tearing easily with incorrect latch, infant pulling on the nipple to maintain latch, or an infant biting. Preventive and remedial options are an important aspect of giving mothers the power of self-care in their situation. Engorgement in mothers with hyperplastic breast tissue can be very extreme as their tissue will continue expanding with the increasing pressure if milk is not removed. In theory, some mothers may struggle with achieving let-down due to difficulties with proprioceptive nerves [18]. Conversely, the authors have observed that some mothers with EDS have a strong let-down with high pressure flow of the milk due to the dysfunctional collagen which coordinates the smooth muscle movement of mammary tissue. Engorgement is worth preventing with regular, frequent feeds in the early days of lactation. Extreme engorgement can also occur during breastfeeding transitions, such as infant growth spurts and cessation of breastfeeding, making education on transitioning and gradual weaning techniques an imperative.

In cases of let-down difficulty, stress reduction, reassurance, and breast massage can help provide stronger visual / auditory / tactile cues to stimulate oxytocin release and myoepithelial contraction of the alveoli and milk ducts. 
For those with strong let-down, repositioning the infant into a sitting position can help the infant manage the high-pressure flow that results from strong let-down.

\section{Dysautonomia}

Dysautonomia is a dysfunction of the nerves that regulate involuntary body functions, such as perspiration, blood pressure, and heart rate. Many patients with EDS have associated diagnoses that classify as dysautonomia such as postural orthostatic tachycardia syndrome (POTS) [53, 54]. These problems with the autonomic ("fight, flight, or freeze") nervous system can lead to rapid lowering of blood pressure often upon standing, or an excessively fast heart rate, which can be challenging to cope with as such symptoms, like dizziness, palpitations, or (near) fainting, are often not quantifiable and can be misdiagnosed as the "anxiety" of being a new mother. While these autonomic symptoms may require medication, there are often mechanical and precautionary strategies that are also implemented, such as compression leggings and particular physiotherapy regimens. Mothers who experience near fainting with standing due to dysautonomia should be cautioned against standing quickly and should be advised, for the safety of both, to pick the infant up after standing rather than hold the infant and stand up.

\section{Conclusions}

Although scant information is available on mothers with EDS and their challenges during lactation, from the research available and the commonly accepted aspects of EDS treatment recommendations can be compiled. Given that this topic is relatively novel and modern medicine is working towards improving our understanding of EDS there is a limitation to the application of generalized recommendations. These compiled discussions of treatment options should be used at the discretion and best judgment of the necessary medical providers.

Each mother may have a combination of signs and symptoms that are unique to them, and all mothers should be treated on a case-by-case basis. Some mothers with EDS may have various types of pain with feeding at the breast or expressing milk while others may have none. As with any patient, it is crucial to take a full health history to develop a precise, targeted care plan. As EDS has 13 subtypes, there can be overlaps in the signs and symptoms of a particular patient to several subtypes, and while every subtype of EDS has unique risks for mothers [55], there is a great deal of overlap in terms of the experiences of such mothers in their obstacles to a successful lactation experience. Unfortunately, their symptoms may be overlooked or not addressed given the lack of practitioners' exposure to the condition. Watching a mother with EDS, listening closely to what is said, and working with the health care team to provide all aspects of lactation support are crucial to helping this unique patient on the path to achieving their lactation goals. Research is needed to address gaps in existing knowledge regarding EDS and lactation which will facilitate evidence-based practice in the support of lactating mothers with EDS.

\section{Abbreviations \\ EDS: Ehlers-Danlos syndrome; Gl: Gastrointestinal; KT tape: Kinesiology therapeutic tape; TENS: Transcutaneous electrical nerve stimulation}

\section{Acknowledgments}

We would like to thank all the families who have shared their lives with us over the years.

\section{Authors' contributions}

Each of the authors contributed equally to the conceptualization, design, writing, and editing of the manuscript. The author(s) read and approved the final manuscript.

\section{Funding}

The authors received no financial support for the research, authorship, and / or publication of this article.

\section{Availability of data and materials}

Not applicable.

\section{Declarations}

Ethics approval and consent to participate

Not applicable.

Consent for publication

Not applicable.

\section{Competing interests}

The authors declare that they have no potential conflicts of interest with respect to the research, authorship, and / or publication of this article.

\section{Author details}

${ }^{1}$ University of Texas at San Antonio Libraries, San Antonio, TX, USA.

${ }^{2}$ Foundation for Maternal, Infant, and Lactation Knowledge, San Antonio, TX, USA.

Received: 23 April 2021 Accepted: 13 December 2021

Published online: 04 January 2022

\section{References}

1. Malfait F, Francomano C, Byers P, Belmont J, Berglund B, Black J, et al. The 2017 international classification of the Ehlers - Danlos syndromes. Am J Med Genet C Semin Med Genet. 2017;175(1):8-26. https://doi.org/10.1002/a jmg.c.31552.

2. Forghani I. Updates in clinical and genetics aspects of hypermobile Ehlers Danlos syndrome. Balkan Med J. 2019;36(1):12-6. https://doi.org/10.4274/ba Ikanmedj.2018.1113.

3. Brady AF, Demirdas S, Fournel-Gigleux S, Ghali N, Giunta C, KapfererSeebacher I, et al. The Ehlers-Danlos syndromes, rare types. Am J Med Genet C Semin Med Genet. 2017;175(1):70-115. https://doi.org/10.1002/a jmg.c.31550.

4. Henderson FC, Austin C, Benzel E, Bolognese P, Ellenbogen R, Francomano CA, et al. Neurological and spinal manifestations of the Ehlers-Danlos syndromes. Am J Med Genet C Semin Med Genet. 2017;175(1):195-211. https://doi.org/10.1002/ajmg.c.31549.

5. Ritelli M, Colombi M. Molecular genetics and pathogenesis of Ehlers-Danlos syndrome and related connective tissue disorders. Genes. 2020;11(5):547. https://doi.org/10.3390/genes11050547.

6. Colombi M, Dordoni C, Chiarelli N, Ritelli M. Differential diagnosis and diagnostic flow chart of joint hypermobility syndrome/ehlers-danlos 
syndrome hypermobility type compared to other heritable connective tissue disorders. Am J Med Genet C Semin Med Genet. 2015;169C(1):6-22. https://doi.org/10.1002/ajmg.c.31429.

7. Malfait F, Castori M, Francomano CA, Giunta C, Kosho T, Byers P. The EhlersDanlos syndromes. Nat Rev Dis Prim. 2020;6(1):64. https://doi.org/10.1038/ s41572-020-0194-9.

8. Song B, Yeh P, Harrell J. Systemic manifestations of Ehlers-Danlos syndrome. Baylor Univ Med Cent Proc. 2021;34(1):49-53. https://doi.org/10.1080/089982 80.2020.1805714

9. Scheper M, Rombaut L, de Vries J, De Wandele I, van der Esch M, Visser B, et al. The association between muscle strength and activity limitations in patients with the hypermobility type of Ehlers-Danlos syndrome: the impact of proprioception. Disabil Rehabil. 2017;39(14):1391-7. https://doi.org/10.1 080/09638288.2016.1196396.

10. Tinkle B, Castori M, Berglund B, Cohen H, Grahame R, Kazkaz H, et al. Hypermobile Ehlers-Danlos syndrome (a.k.a. Ehlers-Danlos syndrome type III and Ehlers-Danlos syndrome hypermobility type): clinical description and natural history. Am J Med Genet Part C Semin Med Genet. 2017;175(1):4869. https://doi.org/10.1002/ajmg.c.31538.

11. Demmler JC, Atkinson MD, Reinhold EJ, Choy E, Lyons RA, Brophy ST. Diagnosed prevalence of Ehlers-Danlos syndrome and hypermobility spectrum disorder in Wales, UK: a national electronic cohort study and casecontrol comparison. BMJ Open. 2019;9(11):31365. https://doi.org/10.1136/ bmjopen-2019-031365.

12. Terry RH, Palmer ST, Rimes KA, Clark CJ. Living with joint hypermobility syndrome: patient experiences of diagnosis, referral, and self-care. Fam Pract. 2015;32(3):354-8. https://doi.org/10.1093/fampra/cmv026.

13. Bani D. Relaxin: a pleiotropic hormone. Gen Pharmacol. 1997;28(1):13-22. https://doi.org/10.1016/s0306-3623(96)00171-1.

14. Sundelin HEK, Stephansson O, Johansson K, Ludvigsson JF. Pregnancy outcome in joint hypermobility syndrome and Ehlers-Danlos syndrome. Acta Obstet Gynecol Scand. 2017;96(1):114-9. https:/doi.org/10.1111/aogs.13043.

15. Karthikeyan A, Venkat-Raman N. Hypermobile Ehlers-Danlos syndrome and pregnancy. Obstet Med. 2018;11(3):104-9. https://doi.org/10.1177/17534 95X18754577.

16. Shalhub S, Sage L, Demasi J, Wallace SE, Fulton DS, Bloom L, et al. Shalhub S, Sage L, Demasi J, Wallace SE, Fulton DS, Bloom L, Driessnack M, Byers PH; Vascular Ehlers-Danlos Syndrome Collaborative. Assessment of the Information Sources and Interest in Research Collaboration Among Individuals with Vascular Ehlers-Danlos Syndrome. Ann Vasc Surg. 2020;62:326-34. https://doi.org/10.1016/j.avsg.2019.06.010.

17. Gazit Y, Jacob G, Grahame R. Ehlers-Danlos syndrome-hypermobility type: a much neglected multisystemic disorder. Rambam Maimonides Med J. 2016;7(4):e0034. https://doi.org/10.5041/RMMJ.10261.

18. Bernal M, Chammings F, Couade M, Bercoff J, Tanter M, Gennisson JL. In vivo quantification of the nonlinear shear modulus in breast lesions: feasibility study. IEEE Trans Ultrason Ferroelectr Freq Control. 2016;63(1):1019. https://doi.org/10.1109/TUFFC.2015.2503601

19. Rehnke RD, Groening RM, Van Buskirk ER, Clarke JM. Anatomy of the superficial fascia system of the breast: a comprehensive theory of breast fascial anatomy. Plast Reconstr Surg. 2018;142(5):1135-44. https://doi.org/1 0.1097/PRS.0000000000004948.

20. Gefen A, Farid KJ, Shaywitz I. A review of deep tissue injury development, detection, and prevention: shear savry. Ostomy Wound Manage. 2013;59(2):26-35.

21. Syx D, De Wandele I, Rombaut L, Malfait F. Hypermobility, the Ehlers-Danlos syndromes and chronic pain. Clin Exp Rheumatol. 2017;35(5):116-22.

22. Johannessen EC, Reiten HS, Løvaas H, Maeland S, Juul-Kristensen B. Shoulder function, pain and health related quality of life in adults with joint hypermobility syndrome/Ehlers-Danlos syndrome-hypermobility type. Disabil Rehabil. 2016;38(14):1382-90. https://doi.org/10.3109/09638288.2015.1102336

23. Chopra P, Tinkle B, Hamonet C, Brock I, Gompel A, Bulbena A, et al. Pain management in the Ehlers-Danlos syndromes. Am J Med Genet C Semin Med Genet. 2017;175(1):212-9. https://doi.org/10.1002/ajmg.c.31554.

24. Zhou Z, Rewari A, Shanthanna H. Management of chronic pain in EhlersDanlos syndrome. Medicine (Baltimore). 2018;97(45):e13115. https://doi. org/10.1097/MD.0000000000013115

25. Coluzzi F, Valensise $H$, Sacco M, Allegri M. Chronic pain management in pregnancy and lactation. Minerva Anestesiol. 2014;80(2):211-24.

26. Cazzato D, Castori M, Lombardi R, Caravello F, Bella ED, Petrucci A, et al. Small fiber neuropathy is a common feature of Ehlers-Danlos syndromes. Neurology. 2016;87(2):155-9. https://doi.org/10.1212/WNL.0000000000002847.
27. Castori M, Camerota F, Celletti C, Danese C, Santilli V, Saraceni V, et al. Natural history and manifestations of the hypermobility type Ehlers-Danlos syndrome: a pilot study on 21 patients. Am J Med Genet A. 2010;152A(3): 556-64. https://doi.org/10.1002/AJMG.A.33231.

28. Rodgers KR, Gui J, Dinulos MBP, Chou RC. Ehlers-Danlos syndrome hypermobility type is associated with rheumatic diseases. Sci Rep. 2017;7:17. https://doi.org/10.1038/srep39636.

29. Castori M, Morlino S, Pascolini G, Blundo C, Grammatico P. Gastrointestinal and nutritional issues in joint hypermobility syndrome/ehlers-danlos syndrome, hypermobility type. Am J Med Genet Part C Semin Med Genet. 2015;169(1):54-75. https://doi.org/10.1002/ajmg.c.31431.

30. Patil NA, Rosengren KJ, Separovic F, Wade JD, Bathgate RAD, Hossain MA. Relaxin family peptides: structure-activity relationship studies. $\mathrm{Br} \mathrm{J}$ Pharmacol. 2017;174(10):950-61. https://doi.org/10.1111/bph.13684.

31. Conrad KP. Maternal vasodilation in pregnancy: the emerging role of relaxin Am J Physiol Regul Integr Comp Physiol. 2011;301(2):R267-75. https://doi. org/10.1152/ajpregu.00156.201.

32. Kent JC, Ashton E, Hardwick CM, Rowan MK, Chia ES, Fairclough KA, et al. Nipple pain in breastfeeding mothers: incidence, causes and treatments. Int J Environ Res Public Health. 2015;12(10):12247-63. https://doi.org/10.3390/ ijerph121012247.

33. Cohen JS. High-dose oral magnesium treatment of chronic, intractable erythromelalgia. Ann Pharmacother. 2002;36(2):255-60. https://doi.org/1 0.1345/aph.1A186.

34. Anderson PO. Drug treatment of Raynaud's phenomenon of the nipple. Breastfeed Med. 2020;15(11):686-8. https://doi.org/10.1089/bfm.2020.0198.

35. Witt AM, Bolman M, Kredit S, Vanic A. Therapeutic breast massage in lactation for the management of engorgement, plugged ducts, and mastitis. J Hum Lact. 2016;32(1):123-31. https://doi.org/10.1177/089033441 5619439.

36. Gibson W, Wand B, Meads C, Catley M, O'Connell N. Transcutaneous electrical nerve stimulation (TENS) for chronic pain - an overview of Cochrane reviews. Cochrane Database Syst Rev. 2019;4(4):CD011890. https:// doi.org/10.1002/14651858.CD011890.pub3.

37. Gudin J, Nalamachu S. Utility of lidocaine as a topical analgesic and improvements in patch delivery systems. Postgrad Med. 2020;132(1):28-36. https://doi.org/10.1080/00325481.2019.1702296.

38. Morland-Schultz K, Hill PD. Prevention of and therapies for nipple pain: a systematic review. J Obstet Gynecol Neonatal Nurs. 2005;34(4):428-37. https://doi.org/10.1177/0884217505276056.

39. Malhotra A, Pace A, Ruiz Maya T, Colman R, Gelb BD, Mehta L, et al. Headaches in hypermobility syndromes: a pain in the neck. Am J Med Genet A. 2020;182(12):2902-8. https://doi.org/10.1002/ajmg.a.61873.

40. Yan CF, Hung YC, Gau ML, Lin KC. Effects of a stability ball exercise programme on low back pain and daily life interference during pregnancy. Midwifery. 2014;30:412-9. https://doi.org/10.1016/j.midw.2013.04.011.

41. Leung RW, Li JF, Leung MK, Fung BK, Fung LC, Tai SM, et al. Efficacy of birth ball exercises on labour pain management. Hong Kong Med J. 2013;19(5): 393-9. https://doi.org/10.12809/hkmj133921.

42. Tseng PC, Puthussery S, Pappas Y, Gau ML. A systematic review of randomised controlled trials on the effectiveness of exercise programs on lumbo pelvic pain among postnatal women. BMC Pregnancy Childbirth. 2015;15(1):316. https://doi.org/10.1186/s12884-015-0736-4.

43. Abdelwahid HH, Wahab BA, Mahmoud MZ, Abukonna A, Saeed Taha EA. Effects of gestational hypertension in the pulsatility index of the middle cerebral and umbilical artery, cerebro-placental ratio, and associated adverse perinatal outcomes. J Radiat Res Appl Sci. 2018;11(3):195-203. https://doi. org/10.1016/j.jrras.2018.02.001.

44. Anderson L, Kynoch K, Kildea S, Lee N. Effectiveness of breast massage for the treatment of women with breastfeeding problems: a systematic review. JBI Evid Synth. 2019;17(8):1668-94. https://doi.org/10.11124/JBISRIR-2017-003932.

45. Cupler ZA, Alrwaily M, Polakowski E, Mathers KS, Schneider MJ. Taping for conditions of the musculoskeletal system: an evidence map review. Chiropr Man Thera. 2020;28(1):52. https://doi.org/10.1186/s12998-020-00337-2.

46. Edmonds DW, McConnell J, Ebert JR, Ackland TR, Donnelly CJ. Biomechanical, neuromuscular and knee pain effects following therapeutic knee taping among patients with knee osteoarthritis during walking gait. Clin Biomech. 2016;39:38-43. https://doi.org/10.1016/j. clinbiomech.2016.09.003.

47. Rahlf AL, Braumann KM, Zech A. Kinesio taping improves perceptions of pain and function of patients with knee osteoarthritis: a randomized, 
controlled trial. J Sport Rehabil. 2019;28(5):481-7. https://doi.org/10.1123/ jsr.2017-0306.

48. Sampey B. Doula My Soul. Camas. https://www.doulamysoul.com/a boutbryna. Accessed 25 Mar 2021.

49. Baeza-Velasco C, Van den Bossche T, Grossin D, Hamonet C. Difficulty eating and significant weight loss in joint hypermobility syndrome/Ehlers-Danlos syndrome, hypermobility type. Eat Weight Disord. 2016;21(2):175-83. https:// doi.org/10.1007/s40519-015-0232-x.

50. Fikree A, Chelimsky G, Collins H, Kovacic K, Aziz Q. Gastrointestinal involvement in the Ehlers-Danlos syndromes. Am J Med Genet Part C Semin Med Genet. 2017;175:181-7. https://doi.org/10.1002/ajmg.c.31546.

51. Baeza-Velasco C, Lorente S, Tasa-Vinyals E, Guillaume S, Mora M, Espinoza P. Gastrointestinal and eating problems in women with Ehlers-Danlos syndromes. Eat Weight Disord. 2021;26(8):2645-56. https://doi.org/10.1007/ s40519-021-01146-z.

52. Hermanns-Lê T, Piérard G. Ultrastructural alterations of elastic fibers and other dermal components in Ehlers-Danlos syndrome of the hypermobile type. Am J Dermatopathol. 2007;29(4):370-3. https://doi.org/10.1097/DAD. 0b013e3180de3ec0.

53. Garland EM, Celedonio JE, Raj SR. Postural tachycardia syndrome: beyond orthostatic intolerance. Curr Neurol Neurosci Rep. 2015;15(9):60. https://doi. org/10.1007/S11910-015-0583-8.

54. Hakim A, O'Callaghan C, De Wandele I, Stiles L, Pocinki A, Rowe P. Cardiovascular autonomic dysfunction in Ehlers-Danlos syndrome-hypermobile type. Am J Med Genet C Semin Med Genet. 2017; 175(1):168-74. https://doi.org/10.1002/ajmg.c.31543.

55. Pezaro S, Pearce G, Reinhold E. Hypermobile Ehlers-Danlos Syndrome during pregnancy, birth, and beyond. Br J Midwifery. 2018;26(4):217-23

https://www.britishjournalofmidwifery.com/content/clinical-practice/a-clinica I-update-on-hypermobile-ehlers-danlos-syndrome-during-pregnancy-birth-a nd-beyond Accessed 02 Nov 2021.

\section{Publisher's Note}

Springer Nature remains neutral with regard to jurisdictional claims in published maps and institutional affiliations.

Ready to submit your research? Choose BMC and benefit from:

- fast, convenient online submission

- thorough peer review by experienced researchers in your field

- rapid publication on acceptance

- support for research data, including large and complex data types

- gold Open Access which fosters wider collaboration and increased citations

- maximum visibility for your research: over $100 \mathrm{M}$ website views per year

At $\mathrm{BMC}$, research is always in progress.

Learn more biomedcentral.com/submissions 